\title{
Unravelling population genetic structure with mitochondrial DNA in a notional panmictic coastal crab species: sample size makes the difference
}

Sara Fratini ${ }^{1}$, Lapo Ragionieri ${ }^{1,2}$, Temim Deli ${ }^{3}$, Alexandra Harrer ${ }^{4}$, Ilaria A. M. Marino ${ }^{5}$, Stefano Cannicci ${ }^{1,6}$, Lorenzo Zane ${ }^{5,7^{*}}$ (D) and Christoph D. Schubart ${ }^{4}$

\begin{abstract}
Background: The extent of genetic structure of a species is determined by the amount of current gene flow and the impact of historical and demographic factors. Most marine invertebrates have planktonic larvae and consequently wide potential dispersal, so that genetic uniformity should be common. However, phylogeographic investigations reveal that panmixia is rare in the marine realm. Phylogeographic patterns commonly coincide with geographic transitions acting as barriers to gene flow. In the Mediterranean Sea and adjoining areas, the best known barriers are the Atlantic-Mediterranean transition, the Siculo-Tunisian Strait and the boundary between Aegean and Black seas. Here, we perform the so far broadest phylogeographic analysis of the crab Pachygrapsus marmoratus, common across the north-eastern Atlantic Ocean, Mediterranean and Black seas. Previous studies revealed no or weak genetic structuring at meso-geographic scale based on mtDNA, while genetic heterogeneity at local scale was recorded with microsatellites, even if without clear geographic patterns. Continuing the search for phylogeographic signal, we here enlarge the mtDNA dataset including 51 populations and covering most of the species' distribution range.

Results: This enlarged dataset provides new evidence of three genetically separable groups, corresponding to the Portuguese Atlantic Ocean, Mediterranean Sea plus Canary Islands, and Black Sea. Surprisingly, hierarchical AMOVA and Principal Coordinates Analysis agree that our Canary Islands population is closer to western Mediterranean populations than to mainland Portugal and Azores populations. Within the Mediterranean Sea, we record genetic homogeneity, suggesting that population connectivity is unaffected by the transition between the western and eastern Mediterranean. The Mediterranean metapopulation seems to have experienced a relatively recent expansion around 100,000 years ago.

Conclusions: Our results suggest that the phylogeographic pattern of $P$. marmoratus is shaped by the geological history of Mediterranean and adjacent seas, restricted current gene flow among different marginal seas, and incomplete lineage sorting. However, they also caution from exclusively testing well-known biogeographic barriers, thereby neglecting other possible phylogeographic patterns. Mostly, this study provides evidence that a geographically exhaustive dataset is necessary to detect shallow phylogeographic structure within widespread marine species with larval dispersal, questioning all studies where species have been categorized as panmictic based on numerically and geographically limited datasets.
\end{abstract}

Keywords: Phylogeography, Larval dispersal, Mediterranean Sea, Crustacea Brachyura, mtDNA Coxl

\footnotetext{
* Correspondence: lorenzo.zane@unipd.it

${ }^{5}$ Department of Biology, University of Padua, via U. Bassi 58/B, 35131 Padova, Italy

${ }^{7}$ Consorzio Nazionale Interuniversitario per le Scienze del Mare, Piazzale

Flaminio 9, 00196 Rome, Italy

Full list of author information is available at the end of the article
} 


\section{Background}

Terrestrial and marine biogeographic regions all over the world are defined based on the distribution of extant species. Boundaries separating adjacent regions may derive from historical breaks or from present-day environmental differences and may contribute to giving rise to genetic discontinuities within species and to allopatric speciation events.

The Mediterranean Sea has a long and complex geological history that has contributed to its high biodiversity and high proportion of endemisms [1]. This epeiric sea is a remnant of the Tethys Sea, and since the Miocene it experienced periods of desiccations (the Messinian Salinity Crisis around 5.5 Mya as well as during various Quaternary glaciations) and subsequent flooding from the Atlantic Ocean. The current biota is therefore mainly linked to colonization from the Atlantic, after the opening of the Strait of Gibraltar in the early Pliocene [1].

Based on range distributions, community composition of marine fauna and differences in salinity and winter surface temperatures, the Mediterranean Sea can be subdivided in two main basins, a western and an eastern one, separated by the Strait of Sicily [2]. Moreover, both basins can be subdivided into sub-basins (Fig. 1): the western basin includes the Alboran Sea, in strict connection with the Atlantic Ocean, Balearic Sea, Ligurian Sea and Tyrrhenian Sea (Fig. 1); while the eastern basin includes the Ionian Sea, the Aegean Sea, communicating with the Black Sea through the Marmara Sea, and the Levantine Sea, now in direct connection with the Red Sea (Fig. 1). The Adriatic Sea is separated from the rest of the eastern basin by the Strait of Otranto.

Boundaries among basins and sub-basins can act as barriers to dispersal of marine organisms at different orders of magnitude, shaping intra- and inter-specific marine diversity (reviewed in [3]). Evident phylogenetic and phylogeographic breaks are those associated with two main geographical transitions: the Atlantic-Mediterranean transition at Strait of Gibraltar or the Almería-Oran Front, and the transition separating the western and eastern Mediterranean basins at the Strait of Sicily (reviewed in [3]). For example, Zane et al. [4] and Papetti et al. [5] recorded the occurrence of separated evolutionary units of the euphausiid Meganyctiphanes norvegica corresponding to the north-eastern Atlantic, the western Atlantic, the Alboran Sea and the Mediterranean Sea. The swordfish Xiphias gladius is another example of genetic isolation among Atlantic and Mediterranean populations [6] and genetic distinctiveness of eastern and western Mediterranean populations [7]. A similar pattern is also reported for the European spiny lobster Palinurus elephas notwithstanding its long larval phase, with the existence of separated gene pools in the Atlantic Ocean, the western and eastern Mediterranean Sea, respectively [8-10].

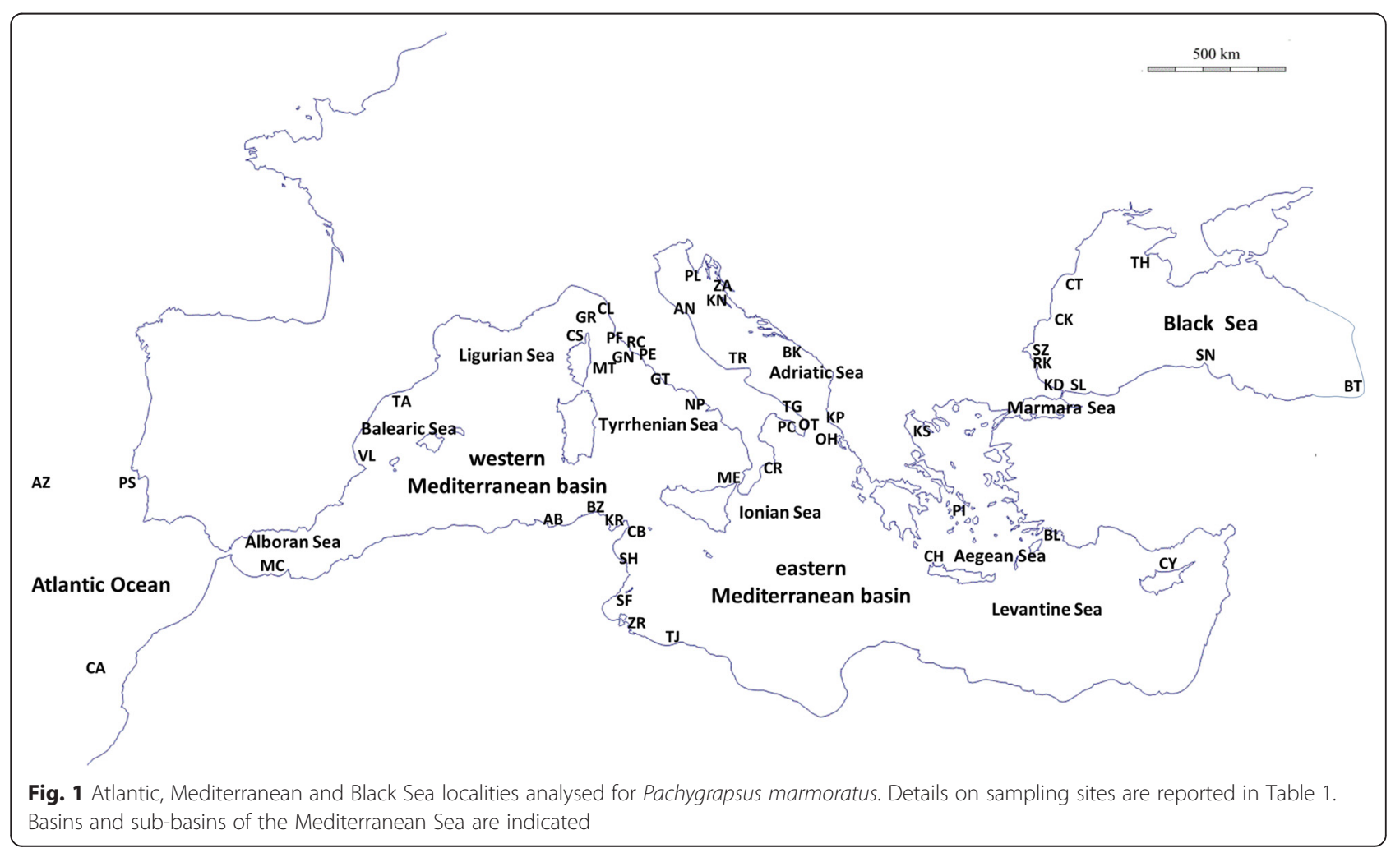


Another relevant phylogeographic transition is the boundary between the eastern Mediterranean basin and the Black Sea through the Marmara Sea. The Black Sea is a relatively small semi-enclosed body of water differentiated from the adjacent Aegean Sea in terms of its chemo-physical conditions and biodiversity [11]. Currently, this area is connected by a two-way water exchange, but this connection is relatively recent, since during the last glacial maximum, 20,000 years ago, the global sea level was around $120 \mathrm{~m}$ below its present one. At that time, the Black Sea was totally isolated from the Mediterranean Sea and was successively diluted with fresh water [12]. In recent years, genetic studies have reported striking examples of separated lineages due to this phylogeographic break. The Black Sea bottlenose dolphins Tursiops truncatus, for example, are genetically and morphologically differentiated from Mediterranean and Atlantic conspecifics [13], while the porpoise Phocoena phocoena is represented by an endemic subspecies, P. phocoena relicta, in the Black Sea [14]. Copepods of the genus Calanus constitute another wellstudied example of marine invertebrates whose Black Sea populations are genetically separated from those of the Atlantic, western Mediterranean, Adriatic and Aegean populations [15].

Most of these examples of intraspecific differentiation refer to pelagic species, while few ones report about the influence of seal level changes on benthic coastal species. Thus, the aim of this study is to investigate intraspecific differentiation in one of the most common, widely distributed and best known invertebrate species of the Mediterranean Sea, the marbled crab Pachygrapsus marmoratus (Fabricius, 1787) (Decapoda; Brachyura; Thoracotremata; Grapsidae). This species occupies the upper and middle shore levels of the rocky coasts of the Mediterranean Sea, Black Sea and north-eastern Atlantic Ocean, from Brittany to Morocco, including the Canary Islands, the Azores, and Madeira [16, 17]. Notwithstanding its huge distribution range, the species' suitable habitats over the entire distribution range are locally separated by extensive stretches of sandy beaches. Adults are relatively sedentary [18], and thus connectivity among populations is maintained by the larval stages, developing for about four weeks in the water column [19] before the megalopa re-colonises the coastal habitat. Sequence variation of the mitochondrial DNA (mtDNA) so far indicated rather high levels of genetic exchange in the species at meso-geographic scales, with a weak separation among Atlantic and Mediterranean populations and lack of differentiation within the Mediterranean Sea [20, 21]. Conversely, some genetic heterogeneity at local scales emerged from previous studies investigating microsatellite polymorphisms [22-24]. Overall, these evidences suggest weak departure from panmixia, as initially supposed for this species and call for investigation of the likely influence of different geographic breaks across its distribution range.

In this study, we gathered a very large dataset to investigate regional population genetic structure and phylogeographic pattern of the marbled crab P. marmoratus covering the Atlantic Ocean, the various basins and subbasins of the Mediterranean Sea and the Black Sea (Fig. 1). With respect to the earlier genetic studies [20, 21], new populations from the Adriatic, northern Aegean and Black Sea were included, allowing an extensive investigation of phylogeographic patterns over a large part of the distributional range of $P$. marmoratus. A total of 587 samples from 51 populations were screened for sequence variation at the mitochondrial cytochrome oxidase subunit 1 (mtDNA CoxI) with the twofold aim of: 1) depicting the effect of currently recognised biogeographic breaks on the geographical distribution of intraspecific genetic variation; and 2) uncovering how historical events may have contributed to shape patterns of intra- and inter-population genetic diversities.

\section{Methods \\ Study area}

A total of 587 samples of Pachygrapsus marmoratus were included in the present phylogeographic study, of which 246 were specifically analysed de novo and the remaining 341 had been previously published: 238 sequences from western Mediterranean and Atlantic by Fratini et al. [20], 98 sequences from North Africa and Turkey by Deli et al. [21] and five sequences from the Azores by Matzen da Silva et al. [25]. Specimens were collected from 51 localities of the Mediterranean Sea, Black Sea and Atlantic Ocean, covering most of the distribution range of the species (Table 1 and Fig. 1). For most samples, a chela or a pereiopod was preserved in absolute ethanol, and the animals released. Details on the sampled localities and the number of individuals analysed per population are reported in Fig. 1 and Table 1.

\section{Genetic analysis}

Total genomic DNA extraction was performed from muscle tissue using the Puregene Kit (Gentra Systems) or the Salting Out extraction method [26]. DNAs were resuspended in sterile distilled water and stored at $4{ }^{\circ} \mathrm{C}$ for routine use, or at $-20^{\circ} \mathrm{C}$ for long-term storage.

Selective amplification of 658 basepairs of the mtDNA CoxI was performed as reported in Fratini et al. [20], using the primers COL6b (5'-acaaatcataaagatatygg- $\left.3^{\prime}\right)$ [27] and HCO2198 (5' -taaacttcagggtgaccaaaaaatca-3') [28]. Amplicons were visualized on an $1 \%$ agarose gel, purified by precipitation with Sure Clean (Bioline), resuspended in water, and then sequenced with the ABI 
Table 1 Pachygrapsus marmoratus populations sampled from the Atlantic Ocean, Mediterranean Sea, and Black Sea

\begin{tabular}{|c|c|c|c|c|c|c|c|}
\hline \# & Area & Nation & Population & Cod. & GPS & & $\mathrm{N}$ \\
\hline 1 & \multirow[t]{3}{*}{ Atlantic Ocean } & Portugal & Sesimbra & PS & $38^{\circ} 26.37^{\prime} \mathrm{N}$ & $09^{\circ} 06.92^{\prime} \mathrm{W}$ & 18 \\
\hline 2 & & Spain & Canary |s|: Fuerteventura & CA & $28^{\circ} 03.14^{\prime} \mathrm{N}$ & $14^{\circ} 21.85^{\prime} \mathrm{W}$ & 18 \\
\hline 3 & & Portugal & Azores |s|: Terciera & $A Z$ & $38^{\circ} 48.10^{\prime} \mathrm{N}$ & $27^{\circ} 15.15^{\prime} \mathrm{W}$ & 17 \\
\hline 4 & Mediterranean Sea: Alboran Sea & Morocco & Cala Iris & $M C$ & $35^{\circ} 09.10^{\prime} \mathrm{N}$ & $4^{\circ} 21.59^{\prime} \mathrm{W}$ & 15 \\
\hline 5 & \multirow[t]{2}{*}{ Mediterranean Sea: Balearic Sea } & Spain & Tarragona & TA & $41^{\circ} 06.40^{\prime} \mathrm{N}$ & $01^{\circ} 14.86^{\prime} \mathrm{E}$ & 20 \\
\hline 6 & & Spain & Valencia & $V L$ & $39^{\circ} 26.80^{\prime} \mathrm{N}$ & $0^{\circ} 19.19^{\prime} \mathrm{W}$ & 20 \\
\hline 7 & Mediterranean Sea: Ligurian Sea & France & Corsica: St. Florent & CS & $42^{\circ} 40.82^{\prime} \mathrm{N}$ & $09^{\circ} 17.80^{\prime} \mathrm{E}$ & 15 \\
\hline 8 & \multirow{12}{*}{$\begin{array}{l}\text { Mediterranean Sea: Tyrrhenian Sea and } \\
\text { opposite North African coastline }\end{array}$} & Italy & Calafuria & $\mathrm{CL}$ & $43^{\circ} 28.32^{\prime} \mathrm{N}$ & $10^{\circ} 20.01^{\prime} \mathrm{E}$ & 15 \\
\hline 9 & & Italy & Porto di Follonica & PF & $42^{\circ} 53.26^{\prime} \mathrm{N}$ & $10^{\circ} 47.2^{\prime} \mathrm{E}$ & 5 \\
\hline 10 & & Italy & Porto Ercole & PE & $42^{\circ} 23.65^{\prime} \mathrm{N}$ & $11^{\circ} 12.33^{\prime} \mathrm{E}$ & 15 \\
\hline 11 & & Italy & Giglio Isl. & GN & $42^{\circ} 21.54^{\prime} \mathrm{N}$ & $10^{\circ} 55.27^{\prime} \mathrm{E}$ & 11 \\
\hline 12 & & Italy & Rocchette & $\mathrm{RC}$ & $42^{\circ} 46.58^{\prime} \mathrm{N}$ & $10^{\circ} 47.59^{\prime} \mathrm{E}$ & 14 \\
\hline 13 & & Italy & Montecristo Isl. & MT & $42^{\circ} 20.63^{\prime} \mathrm{N}$ & $10^{\circ} 19.28^{\prime} \mathrm{E}$ & 15 \\
\hline 14 & & Italy & Gorgona Isl. & $G R$ & $43^{\circ} 25.87^{\prime} \mathrm{N}$ & $09^{\circ} 54.40^{\prime} \mathrm{E}$ & 9 \\
\hline 15 & & Italy & Gaeta & GT & $41^{\circ} 12.38^{\prime} \mathrm{N}$ & $13^{\circ} 34.26^{\prime} \mathrm{E}$ & 15 \\
\hline 16 & & Italy & Fusaro & NP & $40^{\circ} 48.80^{\prime} \mathrm{N}$ & $14^{\circ} 02.44^{\prime} \mathrm{E}$ & 15 \\
\hline 17 & & Algeria & Annaba & $A B$ & $36^{\circ} 54.00^{\prime} \mathrm{N}$ & $07^{\circ} 45.14^{\prime} \mathrm{E}$ & 10 \\
\hline 18 & & Tunisia & Bizerte & $B Z$ & $37^{\circ} 16.13^{\prime} \mathrm{N}$ & $09^{\circ} 52.01^{\prime} \mathrm{E}$ & 8 \\
\hline 19 & & Tunisia & Korbos & $\mathrm{KR}$ & $36^{\circ} 49.10^{\prime} \mathrm{N}$ & $10^{\circ} 34.01^{\prime} \mathrm{E}$ & 9 \\
\hline 20 & \multirow{8}{*}{$\begin{array}{l}\text { Mediterranean Sea: Ionian Sea and } \\
\text { opposite North African coastline }\end{array}$} & Italy & Crotone & $C R$ & $39^{\circ} 05.60^{\prime} \mathrm{N}$ & $17^{\circ} 07.68^{\prime} \mathrm{E}$ & 16 \\
\hline 21 & & Italy & Messina & ME & $38^{\circ} 11.46^{\prime} \mathrm{N}$ & $15^{\circ} 33.49^{\prime} \mathrm{E}$ & 16 \\
\hline 22 & & Italy & Porto Cesareo & PC & $40^{\circ} 11.72^{\prime} \mathrm{N}$ & $17^{\circ} 55.08^{\prime} \mathrm{E}$ & 7 \\
\hline 23 & & Tunisia & Cap Bon & $C B$ & $36^{\circ} 51.77^{\prime} \mathrm{N}$ & $11^{\circ} 05.19^{\prime} \mathrm{E}$ & 12 \\
\hline 24 & & Tunisia & Sahel & $\mathrm{SH}$ & $36^{\circ} 10.46^{\prime} \mathrm{N}$ & $10^{\circ} 48.93^{\prime} \mathrm{E}$ & 11 \\
\hline 25 & & Tunisia & Sfax & SF & $34^{\circ} 44.14^{\prime} \mathrm{N}$ & $10^{\circ} 45.00^{\prime} \mathrm{E}$ & 9 \\
\hline 26 & & Tunisia & Zarzis & ZR & $33^{\circ} 30.34^{\prime} \mathrm{N}$ & $11^{\circ} 06.21^{\prime} \mathrm{E}$ & 11 \\
\hline 27 & & Lybia & Tajura & TJ & $32^{\circ} 52.00^{\prime} \mathrm{N}$ & $13^{\circ} 20.43^{\prime} \mathrm{E}$ & 10 \\
\hline 28 & \multirow[t]{10}{*}{ Mediterranean Sea: Adriatic Sea } & Greece & Othonoi & $\mathrm{OH}$ & $39^{\circ} 14.18^{\prime} \mathrm{N}$ & $20^{\circ} 28.72^{\prime} \mathrm{E}$ & 7 \\
\hline 29 & & Italy & Ancona & AN & $43^{\circ} 36.62^{\prime} \mathrm{N}$ & $13^{\circ} 29.10^{\prime} \mathrm{E}$ & 7 \\
\hline 30 & & Italy & Otranto & OT & $40^{\circ} 06.55^{\prime} \mathrm{N}$ & $18^{\circ} 31.15^{\prime} \mathrm{E}$ & 7 \\
\hline 31 & & Italy & Torre Guaceto & TG & $40^{\circ} 43.00^{\prime} \mathrm{N}$ & $17^{\circ} 48.00^{\prime} \mathrm{E}$ & 7 \\
\hline 32 & & Italy & Tremiti: Capraia Is. & TR & $42^{\circ} 08.32^{\prime} \mathrm{N}$ & $15^{\circ} 31.44^{\prime} \mathrm{E}$ & 7 \\
\hline 33 & & Albania & Karaburun Peninsula & KP & $40^{\circ} 23.57^{\prime} \mathrm{N}$ & $19^{\circ} 19.50^{\prime} \mathrm{E}$ & 7 \\
\hline 34 & & Croatia & Kornati & KN & $43^{\circ} 47.54^{\prime} \mathrm{N}$ & $15^{\circ} 16.89^{\prime} \mathrm{E}$ & 7 \\
\hline 35 & & Croatia & Pula & PL & $44^{\circ} 52.12^{\prime} \mathrm{N}$ & $13^{\circ} 50.27^{\prime} \mathrm{E}$ & 18 \\
\hline 36 & & Croatia & Zadar & ZA & $44^{\circ} 07.32^{\prime} \mathrm{N}$ & $15^{\circ} 13.45^{\prime} \mathrm{E}$ & 11 \\
\hline 37 & & Montenegro & Boka Kotorska Bay & BK & $42^{\circ} 23.25^{\prime} \mathrm{N}$ & $18^{\circ} 34.18^{\prime} \mathrm{E}$ & 7 \\
\hline 38 & \multirow{5}{*}{$\begin{array}{l}\text { Mediterranean Sea: Aegean Sea and } \\
\text { Levantine Sea }\end{array}$} & Greece & Crete: Iraklion harbour & $\mathrm{CH}$ & $35^{\circ} 20.41 \mathrm{~N}$ & $25^{\circ} 08.15^{\prime} \mathrm{E}$ & 14 \\
\hline 39 & & Greece & Paros Naoussa harbour & $\mathrm{Pl}$ & $37^{\circ} 07.52^{\prime} \mathrm{N}$ & $25^{\circ} 14.24^{\prime} \mathrm{E}$ & 7 \\
\hline 40 & & Greece & Chalkidiki: Kassandra: Possidi & KS & $39^{\circ} 57.62^{\prime} \mathrm{N}$ & $23^{\circ} 23^{\prime} 52 \mathrm{E}$ & 8 \\
\hline 41 & & Turkey & Lycia: Beldibi & $\mathrm{BL}$ & $36^{\circ} 52.36^{\prime} \mathrm{N}$ & $28^{\circ} 15.97^{\prime} \mathrm{E}$ & 18 \\
\hline 42 & & Cyprus & Girne & $\mathrm{CY}$ & $35^{\circ} 20.56^{\prime} \mathrm{N}$ & $33^{\circ} 18.07^{\prime} \mathrm{E}$ & 22 \\
\hline
\end{tabular}


Table 1 Pachygrapsus marmoratus populations sampled from the Atlantic Ocean, Mediterranean Sea, and Black Sea (Continued)

\begin{tabular}{|c|c|c|c|c|c|c|c|}
\hline$\#$ & Area & Nation & Population & Cod. & GPS & & $\mathrm{N}$ \\
\hline 43 & \multirow[t]{9}{*}{ Black Sea } & Turkey & Sile & $S L$ & $41^{\circ} 10.99^{\prime} \mathrm{N}$ & $29^{\circ} 36.74^{\prime} \mathrm{E}$ & 7 \\
\hline 44 & & Turkey & Sinop & SN & $42^{\circ} 00.96^{\prime} \mathrm{N}$ & $35^{\circ} 10.96^{\prime} \mathrm{E}$ & 7 \\
\hline 45 & & Bulgaria & Sozopol & SZ & $42^{\circ} 25.02^{\prime} \mathrm{N}$ & $27^{\circ} 41.46^{\prime} \mathrm{E}$ & 21 \\
\hline 46 & & Bulgaria & Cape Kaliakra & CK & $43^{\circ} 24.71^{\prime} \mathrm{N}$ & $28^{\circ} 21.00^{\prime} \mathrm{E}$ & 7 \\
\hline 47 & & Bulgaria & Ropotamo-Kiten & RK & $42^{\circ} 11.71^{\prime} \mathrm{N}$ & $27^{\circ} 50.16^{\prime} \mathrm{E}$ & 7 \\
\hline 48 & & Georgia & Batumi & BT & $41^{\circ} 41.28^{\prime} \mathrm{N}$ & $41^{\circ} 42.08^{\prime} \mathrm{E}$ & 7 \\
\hline 49 & & Ukraine & Karadag & $\mathrm{KD}$ & $44^{\circ} 54.37^{\prime} \mathrm{N}$ & $35^{\circ} 15.33^{\prime} \mathrm{E}$ & 7 \\
\hline 50 & & Ukraine & Tarhankut & $\mathrm{TH}$ & $45^{\circ} 20.03^{\prime} \mathrm{N}$ & $32^{\circ} 33.09^{\prime} \mathrm{E}$ & 7 \\
\hline 51 & & Romania & Costinesti & $C T$ & $43^{\circ} 55.53^{\prime} \mathrm{N}$ & $28^{\circ} 38.44^{\prime} \mathrm{E}$ & 7 \\
\hline & Overall & / & / & $\mathrm{O}$ & / & / & 587 \\
\hline & Atlantic Ocean & / & / & A & / & / & 53 \\
\hline & Mediterranean Sea & / & / & M & / & / & 457 \\
\hline & Black Sea & / & / & B & / & / & 77 \\
\hline
\end{tabular}

For each site indicated the provenience basin/sub-basin; the nation; the sampling location; the abbreviation code for populations; the geographical coordinates; the number of analysed specimens are reported.

BigDye terminator mix followed by electrophoresis in an ABI Prism 310 Genetic Analyzer (Applied Biosystem, Foster City, USA) at the University of Florence (Italy), University of Regensburg (Germany) and at the BMRGenomics (http://www.bmr-genomics.it). Unpublished haplotypes were submitted to molecular databases (accession numbers KX529672-KX529696). The sequences were corrected manually with the program CHROMAS version 1.55 (Technelysium Pty Ltd, Queensville, Australia) and aligned by eye with BioEdit ver. 7.2.5 [29].

The nucleotide composition as well as the number and type of mutations were calculated with MEGA6 [30]. The number of haplotypes, the unbiased haplotype diversity corrected for sample size ( $h$, calculating using the Nei's [31] formula $h=\left(1-\sum x_{i}^{2}\right) n / n-1$, where $x_{i}$ is the frequency of a haplotype and $\mathrm{n}$ is the sample size), and the nucleotide diversity $\left(\pi_{\pi}\right.$ : the mean number of differences between all pairs of haplotypes in a population, expressed as percentage) [31] were calculated for each population, the overall population and geographic groups of populations, using the software ARLEQUIN ver. 3.5.2.2 [32].

A minimum spanning network was built with NETWORK version 4.5.0.1 (Shareware Phylogenetic Network Software; http://www.fluxus-engineering.com/sharenet.htm) to assess the intra-specific evolutionary relationships among the haplotypes of $P$. marmoratus. Genetic differentiation among populations was estimated by one-way AMOVA [33], as implemented in ARLEQUIN. Fixation indices $(\Phi)$ [34] were computed using genetic distances (Tajima and Nei model, suggested for unequal nucleotide frequencies [35]). Additional two-way AMOVAs were performed for testing specific biogeographic hypotheses (see Results). Significance levels of pairwise $\Phi$ st values, under the null hypothesis of no differentiation, were computed by permutation tests from 10,000 random permutations of haplotypes between populations and, when appropriate, populations between groups. When needed, multitest corrections were performed following the $\mathrm{B}-\mathrm{H}$ method [36] using the program SGoF+ ([37]; http:// webs.uvigo.es/acraaj/SGoF.htm).

To visualize the occurrence of genetic structure and setting our biogeographic hypotheses, we performed a Principal Coordinates Analysis (PCoA), based on the genetic distances among all pairwise combinations of populations (expressed as $\Phi$ st pairwise values). The analysis was run using the covariance-standardized method as implemented in GenAlex 6.5 [38].

To infer the demographic history of our populations, we applied three neutrality tests to each population, the overall population, and geographic groups of populations: the Tajima's D [39] and the R2 test [40] that use information on the mutation frequency and are appropriate for distinguishing population growth from constant size population; and the Fu's Fs test which is based on information from the haplotype distribution and is more sensitive to the presence of singletons in a sample $[41,42]$. The Tajima's D and Fu's Fs parameters (both expected to be equal to zero under the hypothesis of selective neutrality and population equilibrium) were assessed as implemented in ARLEQUIN, and their significance levels were calculated by generating 1,000 random samples. Significant negative D and Fs values can be interpreted as signatures of population expansion. The R2 test was calculated using DnaSP ver. 5.10 [43] and its significance level was estimated based on 1,000 simulated re-sampling replicates.

Since departures from neutrality are often due to changes in effective population size, we also applied 
Bayesian Skyline plots (BSP) [44] to fit demographic models for $P$. marmoratus, as implemented in BEAST ver. 1.8.3 [45]. BSP plots were generated for the genetically homogeneous geographic groups inferred by AMOVA (see Results section). For the analysis we used a HKY + I model of mutation, the closest model available in BEAST to the model $\operatorname{TrN}+\mathrm{I}$ that was suggested by jMODELTEST version 2.1.10 [46, 47], and a strict molecular clock. Due to the low sample size and the corresponding low number of haplotypes, the MarkovChain Monte Carlo (MCMC) simulations did not reach convergence for Atlantic populations and results are reported only for the Black and the Mediterranean seas. For the Black Sea, two MCMC runs of 100,000,000 iterations, sampling every 100,000 steps, were performed. In the case of the Mediterranean Sea, the two MCMC were run for 1,000,000,000 iterations, sampling every 500,000 steps. Both for the Black Sea and the Mediterranean runs, the first $10 \%$ iterations were discarded as burn-in and LogCombiner [45] was used to combine the replicates. TRACER 1.6 [48] was used to check convergence by measuring Effective Sample Sizes (ESS) of all parameters (ESS $>200$ for each group) and to calculate the mean value, the upper and lower bounds of the $95 \%$ highest posterior density interval of effective population sizes, and to draw skyline plots. Estimation of time since expansion event was inferred from converting mutations units in estimates of years using a CoxI mutation rate of $1.66 \%$ per million years [49].

\section{Results}

Our mtDNA CoxI alignment was cropped to a length of 596 basepairs. It has an A-T rich nucleotide composition $(\mathrm{C}=21.0 \%, \mathrm{~T}=35.9 \%, \mathrm{~A}=25.1 \%$ and $\mathrm{G}=18.0 \%)$, as commonly found in the mitochondrial DNA of arthropods [50]. The dataset included 74 haplotypes, of which 25 are new to science (haplotypes 50-74) (Additional file 1). Haplotypes 1-33 (accession numbers JF930650-82) were already reported in Fratini et al. [20], and haplotypes 34-49 (accession numbers KX549320-KX549335) in Deli et al. [21]. Five sequences from Azores were downloaded from GenBank (accession numbers JQ306088-92; [25]) and correspond to our haplotype 2 . Among the 74 haplotypes, we recorded a total of 59 variables sites, of which 26 are parsimony-informative and 33 singletons (Additional file 1). Most of the mutations are in third triplet positions and only seven are not silent (Additional file 1).

Most haplotypes differ from each other by single or very few mutations (Fig. 2; Additional file 1). The network is well resolved with three main haplotypes; about $73 \%$ of all individuals carry one of these common haplotypes. Haplotype 2 is the most common one and is present in 271 individuals (corresponding to $46.2 \%$ ): 225 out of 457 from the Mediterranean Sea (more than $49 \%$ ), 42 out of 53 from the Atlantic Ocean (around $80 \%$ ), but only 3 of 77 from the Black Sea (around $4 \%$ ). Haplotype 7 is present in 96 individuals and is restricted to the Mediterranean and Black seas, with about $8.5 \%$ (40 individuals) and $73 \%$ (56 individuals) of their sampled specimens, respectively. Haplotype 4 is present in a total of $62(10.6 \%)$ individuals, 61 collected in the Mediterranean Sea (12.5\% of its individuals) and one in the Atlantic Ocean. Haplotype 6 seems to be the ancestral haplotype showing the highest number of connections. In addition, 54 haplotypes (i.e. about $73 \%$ ) are singletons, i.e. present only in one individual. Ten of the fourteen haplotypes found in the Black Sea are restricted to this geographic area, and most of them seem to originate from haplotype 4 . The association between haplotypes and geography is less evident for the Atlantic Ocean, even if three out of seven haplotypes found in this area are endemic. Both Atlantic and Black Sea populations seem to originate from Mediterranean ones.

The average haplotype and nucleotide diversities are $0.75 \pm 0.02$ and $0.27 \pm 0.1$, respectively (Table 2 ). All populations are characterised by low nucleotide diversity indices $(<0.5 \%)$, while haplotype diversity values per population vary from a minimum of $0.0 \pm 0.0$ to a maximum of $0.97 \pm 0.06$ (Table 2). Calculating genetic diversity indices for the three main geographic groups (i.e. Atlantic Ocean, Mediterranean and Black seas), it becomes evident that the Mediterranean Sea has on average higher haplotype and nucleotide diversities in comparison to the Atlantic Ocean and Black Sea (Table 2).

The one-way AMOVA test, based on Tajima and Nei molecular distances, indicates the existence of genetic differentiation among populations $(\Phi \mathrm{st}=0.18, P<0.001)$. After correcting for multiple tests with the B-H method [36], 394 out of 1275 tests result to be statistically significant based on $\Phi$ st pairwise values. The Black Sea populations are genetically separated from all the Atlantic populations with very high $\Phi$ st values (from a maximum of 0.92 recorded for $\mathrm{AZ}$ vs $\mathrm{TH}$ to a minimum of 0.38 for CK vs $\mathrm{CA}$ ) and from most of the Mediterranean populations (Additional file 2). Many significant pairwise comparisons also regard two Atlantic populations, PS and AZ, with respect to the Mediterranean populations (Additional file 2); while only few $\Phi$ st pairwise values involving the comparison between two Mediterranean populations are statistically significant (Additional file 2). The populations from Alboran Sea and from Canary Islands do not show any significant pairwise Фst values in comparison to Atlantic populations from Portugal and Azores, and at the same time they are genetically not differentiated from most of Mediterranean populations (Additional file 2). 


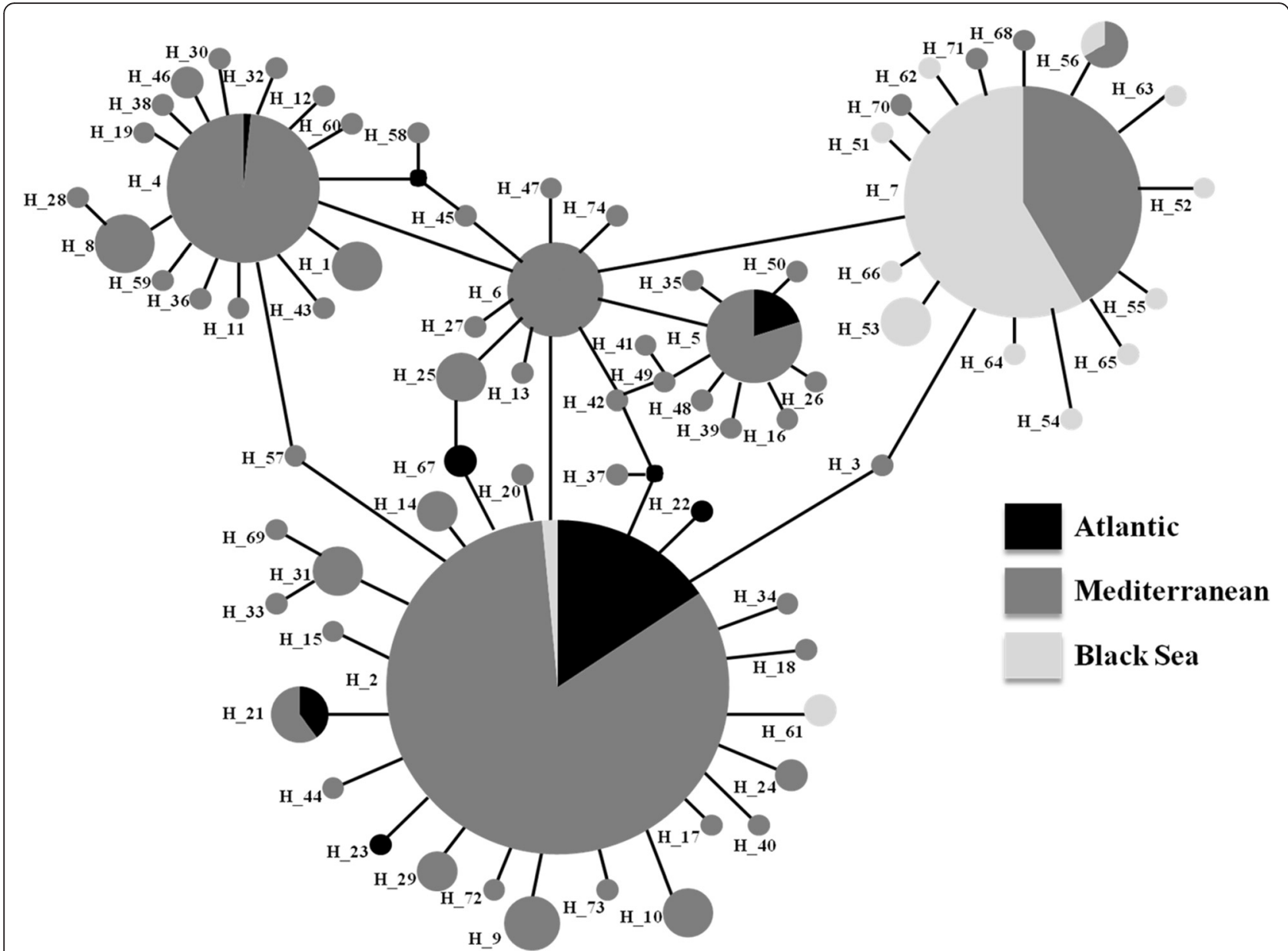

Fig. 2 Minimum spanning network showing the relationships among the recorded haplotypes of Pachygrapsus marmoratus. Each line represents one mutational step. Circles representing haplotypes are scaled to their frequencies. $\mathrm{H} 6$ represents the ancestral haplotype

The PCoA analysis, with axis 1 and axis 2 explaining $63.94 \%$ and $18.3 \%$ of the distribution, respectively, confirm a clear-cut genetic separation of Black Sea populations from Mediterranean and Atlantic ones (Fig. 3). The existence of a separate lineage in the Black Sea is corroborated by the fact that the samples collected in the three geographically closest Mediterranean sites (KS, PI and BL) are not the closest ones in the PCoA ordination, as expected in case of isolation by distance. With regard to the Atlantic samples, only the two northern populations, PS and AZ, cluster together, while the population from Canary Island, $\mathrm{CA}$, cluster within the Mediterranean group and appears to be closely related to MC and VL (i.e. the populations from Alboran and Balearic Sea) (Fig. 3). The PCoA ordination does not reveal any clear subdivision among the Mediterranean populations, confirming the lack of genetic separation between western and eastern basins (Fig. 3).

Based on the $\Phi$ st pairwise comparison values, on the PCoA plot and on the network, we tested some alternative biogeographic hypotheses by applying 2way AMOVAs (Table 3). First, we grouped populations into three geographic groups corresponding to Atlantic Ocean (PS + AZ + CA), Mediterranean Sea, and Black Sea: the analysis recorded a $\Phi$ ct equal to 0.34 $(P<0.001)$. Alternatively, we included the Alboran population within the Atlantic group, for testing the hypothesis that the Atlantic-Mediterranean transition could be located at the Almería-Oran Front in line with the break reported for other species by Patarnello et al. [3]: in this case, the recorded $\Phi$ ct were slightly lower, being equal to $0.32(P<0.001)$. When the Atlantic population from Canary Islands (CA) was grouped with the Mediterranean populations, in line with the PCoA results, the $\Phi$ ct value increased to $0.36(P<0.001)$. Finally, a separation among the main Mediterranean basins was not underlined from a further 2-way AMOVA, splitting the Mediterranean group into three subgroups (i.e. five groups; western Mediterranean $+\mathrm{CA}$ /Adriatic Sea/eastern Mediterranean/ Atlantic/Black Sea), as indicated from the lower $\Phi$ ct value 
Table 2 Genetic diversity and historical demographic results for populations of Pachygrapsus marmoratus from the Atlantic Ocean, Mediterranean Sea and Black Sea

\begin{tabular}{|c|c|c|c|c|c|c|c|c|c|}
\hline$\#$ & Area & Cod. & $\mathrm{N}$ & Nhap & $\mathrm{h}$ & $\pi(\%)$ & T-D & F-Fs & R2 \\
\hline$\overline{1}$ & \multirow[t]{3}{*}{ Atlantic Ocean } & PS & 18 & 3 & $0.22 \pm 0.12$ & $0.01 \pm 0.01$ & -1.71 & -1.02 & 0.17 \\
\hline 2 & & CA & 18 & 6 & $0.62 \pm 0.12$ & $0.18 \pm 0.14$ & -1.21 & -2.14 & 0.09 \\
\hline 3 & & $A Z$ & 17 & 2 & $0.22 \pm 0.12$ & $0.04 \pm 0.05$ & -0.49 & 0.03 & 0.16 \\
\hline 4 & Mediterranean Sea: Alboran Sea & $M C$ & 15 & 6 & $0.57 \pm 0.15$ & $0.15 \pm 0.12$ & -1.45 & -3.23 & 0.09 \\
\hline 5 & \multirow[t]{2}{*}{ Mediterranean Sea: Balearic Sea } & TA & 20 & 9 & $0.82 \pm 0.07$ & $0.28 \pm 0.19$ & -0.89 & -4.14 & 0.09 \\
\hline 6 & & $V L$ & 20 & 5 & $0.44 \pm 0.13$ & $0.18 \pm 0.14$ & -1.44 & -0.85 & 0.1 \\
\hline 7 & Mediterranean Sea: Ligurian Sea & CS & 15 & 7 & $0.72 \pm 0.12$ & $0.25 \pm 0.18$ & -0.72 & -3.38 & 0.11 \\
\hline 8 & \multirow{12}{*}{$\begin{array}{l}\text { Mediterranean Sea: Tyrrhenian Sea and opposite } \\
\text { North African coastline }\end{array}$} & $C L$ & 15 & 5 & $0.64 \pm 0.13$ & $0.24 \pm 0.17$ & -0.28 & -0.67 & 0.13 \\
\hline 9 & & $\mathrm{PF}$ & 5 & 1 & $0.0 \pm 0.0$ & $0.0 \pm 0.0$ & 0.0 & 0.0 & 0.0 \\
\hline 10 & & PE & 15 & 3 & $0.45 \pm 0.13$ & $0.13 \pm 0.11$ & 0.63 & 0.36 & 0.19 \\
\hline 11 & & GN & 11 & 5 & $0.78 \pm 0.09$ & $0.24 \pm 0.0$ & 0.14 & -1.2 & 0.16 \\
\hline 12 & & $\mathrm{RC}$ & 14 & 7 & $0.81 \pm 0.09$ & $0.30 \pm 0.21$ & -0.14 & -2.38 & 0.13 \\
\hline 13 & & MT & 15 & 9 & $0.85 \pm 0.09$ & $0.32 \pm 0.22$ & -1.17 & -6.05 & 0.08 \\
\hline 14 & & GR & 9 & 7 & $0.92 \pm 0.09$ & $0.39 \pm 0.26$ & -1.03 & -4.71 & 0.10 \\
\hline 15 & & GT & 15 & 67 & $0.77 \pm 0.10$ & $0.31 \pm 0.21$ & -1.22 & -2.1 & 0.09 \\
\hline 16 & & $N P$ & 15 & 5 & $0.63 \pm 0.12$ & $0.23 \pm 0.17$ & -0.36 & -0.74 & 0.13 \\
\hline 17 & & $A B$ & 10 & 6 & $0.84 \pm 0.10$ & $0.37 \pm 0.25$ & -0.43 & -1.56 & 0.14 \\
\hline 18 & & $B Z$ & 8 & 5 & $0.79 \pm 0.15$ & $0.32 \pm 0.23$ & -1.36 & -1.23 & 0.12 \\
\hline 19 & & $\mathrm{KR}$ & 9 & 8 & $0.97 \pm 0.06$ & $0.47 \pm 0.31$ & -0.74 & -4.62 & 0.12 \\
\hline 20 & \multirow{8}{*}{$\begin{array}{l}\text { Mediterranean Sea: Ionian Sea and opposite } \\
\text { North African coastline }\end{array}$} & $C R$ & 16 & 5 & $0.53 \pm 0.14$ & $0.18 \pm 0.14$ & -0.89 & -1.18 & 0.11 \\
\hline 21 & & ME & 16 & 7 & $0.82 \pm 0.07$ & $0.29 \pm 0.20$ & -0.66 & -2.19 & 0.12 \\
\hline 22 & & $P C$ & 7 & 3 & $0.67 \pm 0.17$ & $0.24 \pm 0.19$ & 0.75 & 0.67 & 0.22 \\
\hline 23 & & $C B$ & 12 & 6 & $0.76 \pm 0.12$ & $0.27 \pm 0.20$ & -0.67 & -1.87 & 0.12 \\
\hline 24 & & $\mathrm{SH}$ & 11 & 4 & $0.60 \pm 0.15$ & $0.17 \pm 0.14$ & -0.93 & -0.7 & 0.13 \\
\hline 25 & & SF & 9 & 6 & $0.89 \pm 0.09$ & $0.29 \pm 0.21$ & -0.27 & -2.58 & 0.15 \\
\hline 26 & & $\mathrm{ZR}$ & 11 & 7 & $0.82 \pm 0.12$ & $0.36 \pm 0.24$ & -1.27 & -2.65 & 0.09 \\
\hline 27 & & TJ & 10 & 5 & $0.67 \pm 0.16$ & $0.25 \pm 0.18$ & -1.28 & -1.32 & 0.12 \\
\hline 28 & \multirow[t]{10}{*}{ Mediterranean Sea: Adriatic Sea } & $\mathrm{OH}$ & 7 & 3 & $0.77 \pm 0.11$ & $0.26 \pm 0.20$ & 1.11 & 0.79 & 0.25 \\
\hline 29 & & AN & 7 & 6 & $0.95 \pm 0.9$ & $0.41 \pm 0.29$ & -0.69 & -2.7 & 0.15 \\
\hline 30 & & OT & 7 & 3 & $0.67 \pm 0.16$ & $0.27 \pm 0.21$ & -0.04 & 0.9 & 0.22 \\
\hline 31 & & TG & 7 & 6 & $0.95 \pm 0.09$ & $0.30 \pm 0.23$ & -0.56 & -3.55 & 0.14 \\
\hline 32 & & TR & 7 & 3 & $0.71 \pm 0.13$ & $0.20 \pm 0.19$ & 0.75 & 0.67 & 0.22 \\
\hline 33 & & $\mathrm{KP}$ & 7 & 3 & $0.67 \pm 0.16$ & $0.29 \pm 0.22$ & 0.24 & 1.01 & 0.23 \\
\hline 34 & & $\mathrm{KN}$ & 7 & 4 & $0.86 \pm 0.10$ & $0.21 \pm 0.17$ & 0.05 & -1.06 & 0.20 \\
\hline 35 & & $\mathrm{PL}$ & 18 & 6 & $0.81 \pm 0.06$ & $0.23 \pm 0.16$ & -0.2 & -1.54 & 0.13 \\
\hline 36 & & $Z A$ & 11 & 6 & $0.84 \pm 0.09$ & $0.25 \pm 0.18$ & 0.34 & -2.36 & 0.18 \\
\hline 37 & & BK & 7 & 5 & $0.86 \pm 0.14$ & $0.37 \pm 0.26$ & -0.54 & -1.35 & 0.15 \\
\hline 38 & \multirow[t]{5}{*}{ Mediterranean Sea: Aegean Sea and Levantine Sea } & $\mathrm{CH}$ & 14 & 3 & $0.58 \pm 0.09$ & $0.17 \pm 0.14$ & 1.7 & 0.9 & 0.26 \\
\hline 39 & & $\mathrm{Pl}$ & 7 & 5 & $0.86 \pm 0.14$ & $0.29 \pm 0.22$ & -0.79 & -1.89 & 0.11 \\
\hline 40 & & KS & 8 & 5 & $0.76 \pm 0.15$ & $0.26 \pm 0.20$ & -0.92 & -1.75 & 0.11 \\
\hline 41 & & $\mathrm{BL}$ & 18 & 6 & $0.68 \pm 0.11$ & $0.19 \pm 0.15$ & -0.66 & -2.02 & 0.11 \\
\hline 42 & & $\mathrm{CY}$ & 22 & 9 & $0.74 \pm 0.09$ & $0.25 \pm 0.18$ & -1.04 & -4.27 & 0.09 \\
\hline
\end{tabular}


Table 2 Genetic diversity and historical demographic results for populations of Pachygrapsus marmoratus from the Atlantic Ocean, Mediterranean Sea and Black Sea (Continued)

\begin{tabular}{|c|c|c|c|c|c|c|c|c|c|}
\hline$\#$ & Area & Cod. & $\mathrm{N}$ & Nhap & $\mathrm{h}$ & $\pi(\%)$ & $\mathrm{T}-\mathrm{D}$ & F-Fs & $\mathrm{R} 2$ \\
\hline 43 & \multirow[t]{9}{*}{ Black Sea } & $S L$ & 7 & 3 & $0.67 \pm 0.16$ & $0.13 \pm 0.11$ & -0.27 & 1.22 & 0.21 \\
\hline 44 & & SN & 7 & 1 & $0.0 \pm 0.0$ & $0.0 \pm 0.0$ & 0.0 & 0.0 & 0.0 \\
\hline 45 & & $\mathrm{SZ}$ & 21 & 7 & $0.56 \pm 0.13$ & $0.17 \pm 0.13$ & -2.0 & -3.33 & 0.08 \\
\hline 46 & & CK & 7 & 4 & $0.81 \pm 0.13$ & $0.29 \pm 0.22$ & 0.24 & -0.43 & 0.20 \\
\hline 47 & & RK & 7 & 4 & $0.71 \pm 0.18$ & $0.19 \pm 0.16$ & -1.43 & -1.22 & 0.18 \\
\hline 48 & & BT & 7 & 2 & $0.29 \pm 0.20$ & $0.14 \pm 0.13$ & -1.36 & 1.51 & 0.35 \\
\hline 49 & & $\mathrm{KD}$ & 7 & 2 & $0.29 \pm 0.20$ & $0.05 \pm 0.06$ & -1.01 & -0.09 & 0.35 \\
\hline 50 & & $\mathrm{TH}$ & 7 & 1 & $0.0 \pm 0.0$ & $0.0 \pm 0.0$ & 0.0 & 0.0 & 0.0 \\
\hline 51 & & $\mathrm{CT}$ & 7 & 3 & $0.52 \pm 0.21$ & $0.10 \pm 0.10$ & -1.24 & -0.92 & 0.23 \\
\hline & Overall & O & 587 & 74 & $0.75 \pm 0.00$ & $0.27 \pm 0.18$ & -2.26 & -27.11 & 0.01 \\
\hline & Atlantic Ocean & A & 53 & 7 & $0.37 \pm 0.08$ & $0.10 \pm 0.08$ & -1.63 & -3.99 & 0.16 \\
\hline & Mediterranean Sea & M & 457 & 60 & $0.73 \pm 0.02$ & $0.26 \pm 0.17$ & -2.23 & -27.28 & 0.07 \\
\hline & Black Sea & B & 77 & 14 & $0.45 \pm 0.07$ & $0.14 \pm 0.11$ & -2.14 & -12.48 & 0.03 \\
\hline
\end{tabular}

Population and area codes correspond to those reported in Table 1. Values reported are: number of individuals analysed (N); number of haplotypes (Nhap); haplotype $(\mathrm{h})$ and nucleotide $(\pi)$ diversity (the latter expressed in percentage); T-D, Tajima D test; F-Fs, Fu's Fs test; R2, Ramos-Onsins and Rozas R2 test. Significant values $(P<0.05)$ are in bold




Table 3 Analysis of molecular variance testing for partitioning of Pachygrapsus marmoratus genetic variation under alternative biogeographic hypotheses

\begin{tabular}{|c|c|c|c|c|}
\hline Hypothesis & Source of variation & df & F-statistics & $P$ \\
\hline \multicolumn{5}{|l|}{ 1) three groups, geography } \\
\hline - Atlantic (PS + AZ + CA) & Among groups & 2 & $\Phi \mathrm{ct}=0.34$ & $<0.001$ \\
\hline - Mediterranean Sea (including Alboran Sea, MC) & Among pops/within groups & 47 & Dsc $=0.02$ & 0.067 \\
\hline - Black Sea & Among populations & 530 & Dst $=0.35$ & $<0.001$ \\
\hline \multicolumn{5}{|l|}{ 2) three groups, Orano-Almeria front } \\
\hline - Atlantic and Alboran Sea (PS + AZ + CA + MC) & Among groups & 2 & $\Phi \mathrm{ct}=0.32$ & $<0.001$ \\
\hline - Mediterranean Sea (excluding Alboran Sea, MC) & Among pops/within groups & 47 & Dsc $=0.01$ & 0.104 \\
\hline - Black Sea & Among populations & 530 & Фst $=0.33$ & $<0.001$ \\
\hline \multicolumn{5}{|l|}{ 3) three groups, $\mathrm{PCOA}$} \\
\hline - Northernmost Atlantic (PS + AZ) & Among groups & 2 & $\Phi \mathrm{ct}=0.36$ & $<0.001$ \\
\hline - Mediterranean Sea (including Alboran Sea, MC) + Canary Island & Among pops/within groups & 47 & Фsc $=0.02$ & 0.047 \\
\hline - Black Sea & Among populations & 530 & Фst $=0.37$ & $<0.001$ \\
\hline \multicolumn{5}{|l|}{ 4) five groups, differences within Med } \\
\hline \multicolumn{5}{|l|}{ - Northernmost Atlantic (PS + AZ) } \\
\hline - western Mediterranean Sea (including Alboran Sea, MC) + Canary Islands & Among groups & 4 & $\Phi \mathrm{ct}=0.21$ & $<0.001$ \\
\hline - eastern Mediterranean Sea & Among pops/within groups & 45 & Фsc $=0.003$ & 0.387 \\
\hline - Adriatic Sea & Among populations & 530 & Фst $=0.22$ & $<0.001$ \\
\hline - Black Sea & & & & \\
\hline
\end{tabular}

Degrees of freedom (df), F-statistics and P-values are reported. Significant P values are shown in bold. Population abbreviations correspond to those reported in Table 1

respect to those associated to the previous biogeographic hypotheses $\left(\Phi_{\mathrm{ct}}=0.21, P<0.001\right)$.

The neutrality tests provided evidence of departure from mutation-drift equilibrium, since all the tests (Tajima's D, Fu's F and R2 tests) recorded significant values for the overall population and the three geographic groups (i.e. Atlantic Ocean, Mediterranean Sea and Black Sea: Table 2). Considering separately each population, 27 out of 51 of them ( 16 by the Fu's test, only 2 by the Tajima's D test and 21 by the $\mathrm{R} 2$ test) seem to have experienced a recent population expansion (Table 2).

The population demographic history of the Mediterranean and Black seas was reconstructed also applying the BSP analysis. The Mediterranean metapopulation of $P$. marmoratus showed an increase in population size over time (Fig. 4a), whereas the Black Sea metapopulation showed evidence of demographic stability as explained in Grant [51] (Figs. 4b). Converting mutations units in estimates of years using the CoxI mutation rate of $1.66 \%$ per million years [48], the expansion time for Mediterranean group occurred approximately at about 100,000 years ago (CI interval: 60,000-180,000 years ago).

\section{Discussion}

Most marine invertebrates have a planktonic development and consequently a high potential of long ranging gene flow that may blur historic population structuring (for example see [52]). Among the species with a high potential for gene flow there are also decapod Crustacea of the Mediterranean Sea and the north-eastern Atlantic. For example, shallow subtidal crabs of the genus Xantho [53, 54] and Pilumnus [55], the hermit crabs Pagurus excavatus and P. alatus [56], and the pelagic shrimps Parapeneus longirostris and Plesionika heterocarpus [56] show little or no geographic structure within their distribution range. Pachygrapsus marmoratus is another example of species for which genetic homogeneity or only weak structure had been recorded until now, when analysed with mtDNA across a meso-scale geographic area [20, 21]. However, since these previous studies included few populations covering only parts of the species' distribution range, the question arose, if a larger dataset with several hundred individuals and covering most of the species' distribution range, would shed further light on its population genetic structure and unveil phylogeographic patterns.

This was realized in a joined effort in the present paper by investigating phylogeographic and population genetic patterns within the marbled crab $P$. marmoratus with more than 550 individuals from 51 populations distributed from the Atlantic Ocean to the Black Sea. Our results clearly reveal genetic differentiation of populations from the Black Sea from those of the 


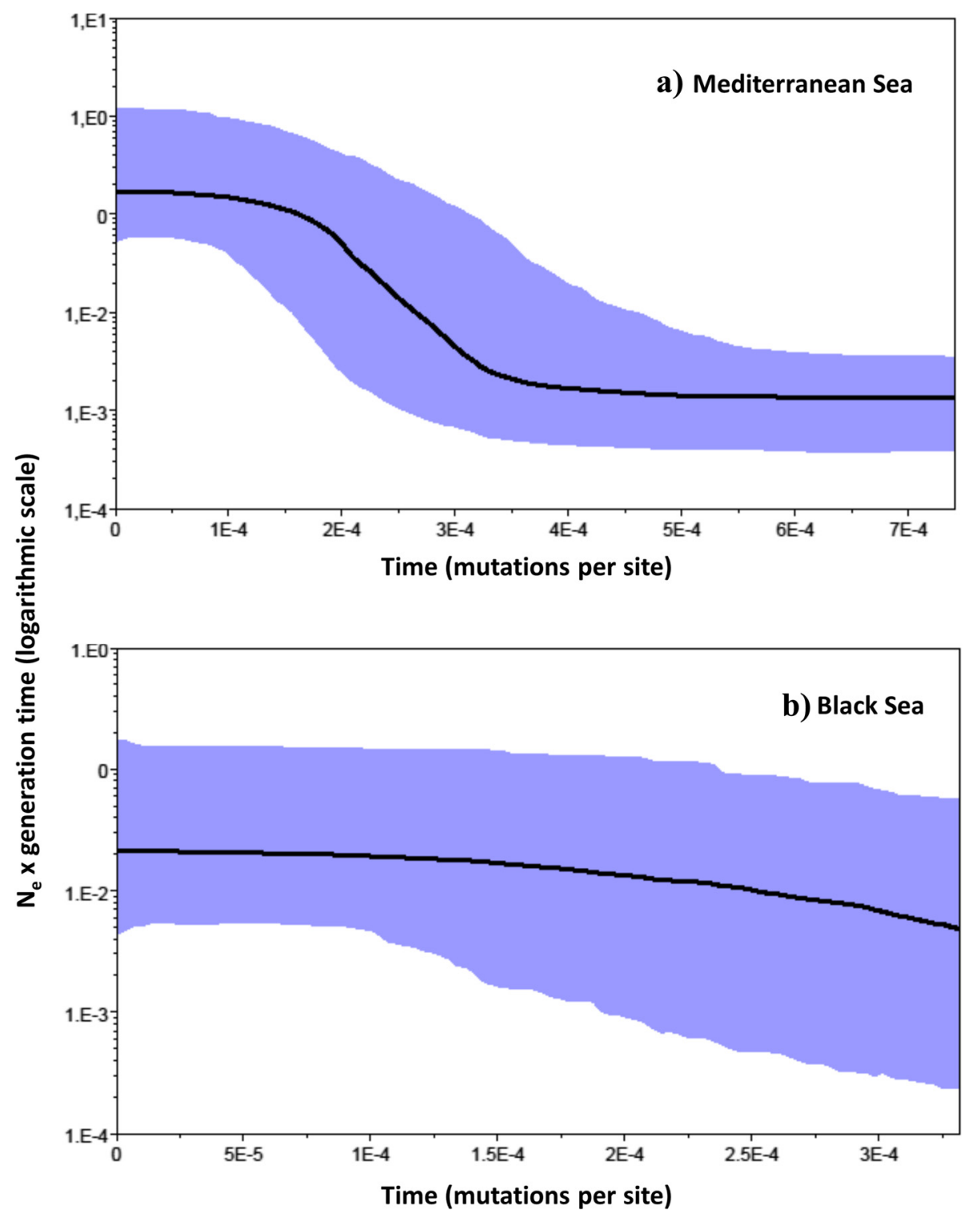

Fig. 4 Bayesian Skyline Plots showing changes in effective population size (expressed as effective population size multiplied per generation time) over time (measured in mutations per site) for the Mediterranean Sea (a) and Black Sea (b) metapopulations. The thick solid line depicts the median estimate and the shaded area represents the highest $95 \%$ posterior density intervals

Mediterranean Sea and Atlantic Ocean. The distribution of genetic variation in P. marmoratus is thus strongly determined by the biogeographic barrier between the Aegean and Black seas, known to restrict dispersal for many marine species at past and present times (reviewed in [3]).

We also recorded the occurrence of a diverging Atlantic lineage comprised of the two more northern Atlantic populations analysed in this study (i.e. the Portuguese populations from Sesimbra and Azores Islands). Interestingly, the here included population from Canary Islands, which is situated southwest to the
Gibraltar Strait, does not appear to belong to the Portuguese Atlantic lineage. A similar latitudinal phylogeographic break has been reported for two limpets of the genus Patella [57] and it was explained by the lack of suitable habitat between Iberian and Atlantic African shores for rocky shores animals. Notwithstanding the notable geographic distance, the Canary Island population results to be closely related to the Alboran and Balearic populations and genetically not distinguishable from the Mediterranean cluster. This could be a historical signature, due to the retention of ancestral haplotypes in the Atlantic and Mediterranean lineages as well 
as incomplete lineage sorting, masking the genetic separation of the Mediterranean populations from this Atlantic population. Nevertheless, we cannot exclude that the Mediterranean-Atlantic transition may currently act as a barrier for P. marmoratus larvae, as reported for other marine species (reviewed in [3]). But a certain permeability may maintain a level of population admixture high enough to allow connectivity between African (including nearby Canary Islands) and Mediterranean populations. In any case, our population from the Alboran Sea is genetically homogenous with respect to the other Mediterranean populations and this result indicates that a potential Mediterranean-Atlantic transition would be located at the Strait of Gibraltar, and not at the Almería-Oran front as reported for many other species (see [3]). Sampling at finer geographic scale along the north-western African coastline, the Atlantic Portuguese and Spanish shores, the Alboran Sea and the Gibraltar Strait will be needed to define both the geographic distribution of Atlantic lineages and the location of the Mediterranean-Atlantic transition. In any case, our data show for the first time the occurrence of a separate lineage within the Atlantic Ocean, corresponding to our sampling sites of the Portuguese mainland and Azores Island. It is interesting that the peripheral Atlantic population of the Azores cannot be statistically distinguished from the continental population from Portugal. Due to the marginal and isolated position of the Azores (approximately $1500 \mathrm{~km}$ from mainland Portugal), this result is rather unexpected. Many genetic studies on fishes reported strong genetic segregations of Azores' population from continental ones [58]. However, we cannot disregard that only two haplotypes, one of which a singleton, were sampled in individuals from this archipelago. This could be due to a founder effect and considered as a first signal of an isolation process.

In this study, we report for the first time sharp geographic breaks in the genetic composition of $P$. marmoratus individuals. Previous population genetic studies based on the same mtDNA marker recorded no or only a subtle separation between Mediterranean and Atlantic populations $[20,21]$. These former studies lacked large numbers of samples from the eastern Mediterranean and Black Sea. This indicates that phylogeographic studies based on high numbers of populations/individuals covering an extensive geographic area allow both to reveal genetic structure that otherwise may remain hidden and to exhaustively examine which evolutionary and demographic forces have shaped the observed patterns of genetic diversity across species' ranges. Overall, our genetic diversity and historical demographic results suggest that the population genetic structure of $P$. marmoratus is the result of the complex geological history of Mediterranean Sea and adjacent seas, past isolation due to Pleistocene glaciations, reduced current gene flow in association with the main geographic boundaries, and incomplete lineage sorting.

As clearly shown by the network and genetic diversity indices, Mediterranean populations present higher average levels of intraspecific genetic variation in comparison to Atlantic and Black Sea populations. This result could be partially produced by the overall larger Mediterranean sample size. However, possible differences in evolutionary history in the different basins may argue against the possibility that it is a simple sampling artefact. The low haplotype and nucleotide diversities observed in the Black Sea and Atlantic population can also be the likely result of a strong bottleneck and founder effect, due to past and current isolation.

Following the opening of the Gibraltar Strait, 5.33 million years ago, most of the Mediterranean marine fauna and flora arrived from the Atlantic Ocean [59]. It is currently unknown if $P$. marmoratus followed this route and expanded within the entire Mediterranean Sea or if it survived the Messinian Salinity Crisis in local refugia within the Mediterranean Sea, as suggested for Carcinus aestuarii by Marino et al. [60], and subsequently expanded to the Atlantic Ocean and Black Sea. In any case, we can suppose that the phylogeographic pattern of $P$. marmoratus has been affected in more recent times by the drastic paleoclimatic events occurring during the Quaternary period. In correspondence to the repeated glaciations and the associated sea level changes during this time, the contact between the Mediterranean Sea and adjoining epeiric seas was likely interrupted, while during interglacial periods it was plausibly re-established. Based on the geographic distribution of haplotypes, we suppose that the main direction of these fluxes was from the Mediterranean to the Atlantic Ocean and Black Sea, as two of the most common haplotypes of the Mediterranean Sea are represented in low percentages in Atlantic and Black Sea populations (i.e. haplotypes 4 and 2, respectively). The BSP results also support the effect of paleoclimatic events on $P$. marmoratus genetic composition, since a clear sign of demographic expansion was found for the Mediterranean metapopulation, dated around 60,000180,000 years ago, i.e. long before the Last Glacial Maximum. In contrast, the Black Sea lineage showed evidence of demographic stability according to the BSP. The Black Sea was a freshwater lake during the Last Glacial Maximum [12] and thus inhospitable for true marine species. Hypothesising that the present colonization of the Black Sea occurred after its last connection with the Aegean Sea, i.e. within the last 10,000 years, our demographic analysis suggests that this process was not accompanied by a sudden population expansion.

Our study recorded genetic homogeneity of $P$. marmoratus within the Mediterranean Sea, as already 
reported from previous studies based on the same mtDNA marker [20, 21]. Therefore, any geographic transitions present at the boundaries among Mediterranean basins and sub-basins do not seem to act as genetic barriers for $P$. marmoratus. Larvae of $P$. marmoratus spend approximately one month in the water column and appear to be able to maintain connectivity among populations, likely following a stepping-stone model, i.e. the most common model for marine species with wide distribution ranges [61, 62]. However, this result is anything but foreseen. In fact, many studies detected the effects of intra-Mediterranean transitions, especially at the Strait of Sicily between western and eastern Mediterranean, on pelagic and benthic species' population genetic structures (reviewed in $[3,60,63]$ ). This confirms that in the marine realm dispersal and connectivity are complex phenomena that cannot be generalised for a certain geographic area, since they strongly depend on the life-history and biological traits of the studied species (see [64]).

High level of gene flow can be the reason for lack of substructure within the Mediterranean Sea. However, we have to keep in mind that genetic studies based on microsatellite polymorphisms [21-24] reported genetic heterogeneity among populations of $P$. marmoratus at local scale, even if without clear association to geography. Fratini et al. [23] hypothesised that larval retention and sweepstake effect could be plausible reasons of limited genetic exchange among the islands forming the Tuscan Archipelago (Tyrrhenian Sea). The finding of local-scale genetic differences in microsatellites could indicate that mtDNA studies may underestimate $P$. marmoratus population structure. Notwithstanding, mtDNA markers do not produce a priori higher estimates of gene flow than hypervariable nuclear markers, as recently stated in Karl et al. [65]. Further population genetic studies based on microsatellite polymorphism and including populations from all the Mediterranean subbasins could help in clarifying the level of present day gene flow across the entire Mediterranean Sea.

\section{Conclusions}

This is the first study to provide clear evidence of genetic differentiation of Pachygrapsus marmoratus across its distribution range and unravel the existence of three distinct phylogeographic lineages, corresponding to the Portuguese Atlantic Ocean, the Mediterranean Sea plus Canary Islands, and the Black Sea. Their genetic distinctiveness is likely the consequence of geological and paleoclimatic processes, historically affecting Mediterranean Sea and adjacent waters, and it may currently be maintained by present-day geographic breaks and species-specific biological traits. Local adaptations to climatic conditions and environmental parameters may contribute to increase the recorded genetic differences among lineages. Morphometric and eco-physiological studies on individuals from the three geographic clusters should be interesting for corroborating this hypothesis.

\section{Additional files}

\begin{abstract}
Additional file 1: Variable sites among 74 mitochondrial haplotypes of P. marmoratus from Atlantic Ocean, Mediterranean and Black seas $(n=587)$. All haplotypes are compared with haplotype $1 .{ }^{*}$, indicates identical nucleotides; PS, parsimonious sites; aa1 and aa2, aminoacids in haplotype 1 and after mutation. Haplotypes 1-33 and 34-49 correspond to those reported in Fratini et al. [20] and Deli et al. [21], respectively. (XLSX 24 kb)

Additional file 2: Pairwise $\Phi$ st values based on Tajima and Nei distance model. In bold are indicated significant values after 10,000 corrections. (XLSX $30 \mathrm{~kb}$ )

Additional file 3: Dataset supporting the conclusions of this article (text file formatted as Arlequin input). Haplotypes 1-33 and 34-49 correspond to those reported in Fratini et al. [20] and Deli et al. [21], respectively. (ARP $52 \mathrm{~kb}$ )
\end{abstract}

\section{Acknowledgements}

Collection of specimens from so many different populations required the help and patience from many accompanying people in the field. Among them are Jose Paula, Ines Silva, Sonya Uzunova, Silke Reuschel, Ruth Jesse, Henrik M. Schubart, Clarissa Schubart, Hermanfrid Schubart, Nicolas Thiercelin, Korbinian Eckel, and Antje Elsäßer, Dragos Micu and Magdalena Nenciu. We are grateful to Carolina Biagi for help with field and laboratory work. This research was supported by Cassa di Risparmio di Firenze Fund and Fondi d'Ateneo 2013-2015, University of Florence (ex $60 \%$, MIUR), to Stefano Cannicci, by the European Union's Seventh Framework Programme for Research, Technological Development and Demonstration under Grant Agreement No. 287844 (CoCoNET) to Lorenzo Zane and Ilaria AM Marino, by the University of Padova grant CPDA148387/14 to Lorenzo Zane and by DAAD exchange projects (PPP) with Italy, Spain, and Bulgaria to CD Schubart.

\section{Availability of data and materials}

The datasets supporting the conclusions of this article are included within the article and in the Additional file 3.

\section{Authors' contributions}

SF, SC, LZ and CDS conceived and funded the study. LR, TD, AH and IAMM carried out the laboratory work. SF, CDS, IAMM, LR, TD and LZ participated in the data analyses. SF, SC, IAMM, LZ and CDS wrote the manuscript. All authors read, commented and approved the final version of manuscript.

\section{Competing interests}

The authors declare that they have no competing interests.

\section{Consent for publication}

Not applicable.

\section{Ethics approval and consent to participate}

None of the sampled $P$. marmoratus populations is endangered or protected by any international or national legal framework. Collections were carried out before 2014 and no specific permissions were required for sampling activities.

\section{Author details}

'Department of Biology, University of Florence, via Madonna del Piano 6, Sesto Fiorentino, Firenze 50019, Italy. ${ }^{2}$ Institute for Zoology, Functional Peptidomics, University of Cologne, Cologne, Germany. ${ }^{3}$ Laboratory of Genetics, Biodiversity and Enhancement of Bioresources (LR11ES41), University of Monastir, Higher Institute of Biotechnology of Monastir, Av. Tahar Hadded, B.P. 74, Monastir 5000, Tunisia. ${ }^{4}$ Zoology and Evolution, Faculty of Biology, University of Regensburg, D-93040 Regensburg, Germany. 
${ }^{5}$ Department of Biology, University of Padua, via U. Bassi 58/B, 35131 Padova, Italy. ${ }^{6}$ The Swire Institute of Marine Science and School of Biological Sciences, The University of Hong Kong, Pokfulam Road, Hong Kong, Hong Kong SAR. ${ }^{7}$ Consorzio Nazionale Interuniversitario per le Scienze del Mare, Piazzale Flaminio 9, 00196 Rome, Italy.

Received: 2 March 2016 Accepted: 5 July 2016

Published online: 26 July 2016

\section{References}

1. Bianchi NC, Morri C. Marine biodiversity of the Mediterranean Sea: situation, problems and prospects for future research. Mar Poll Bull. 2000;40:367-76.

2. Quignard JP. La Mediterranee, creuset ichthyologique. Bolletin Zoologica (Suppl II). 1978;840-45:23-36.

3. Patarnello T, Volckaert FAM, Castilho R. Pillars of Hercules: is the Atlantic-Mediterranean transition a phylogeographic break? Mol Ecol. 2007;16:4426-44.

4. Zane L, Ostellari L, Maccatrozzo L, Bargelloni L, Cuzin-Roudy J, Buchholz F, et al. Genetic differentiation in a pelagic crustacean (Meganyctiphanes norvegica Euphausiacea) from the North east Atlantic and the Mediterranean Sea. Mar Biol. 2000;136:191-9.

5. Papetti C, Zane L, Bortolotto E, Bucklin A, Patarnello T. Genetic differentiation and local temporal stability of population structure in the euphausiid Meganyctiphanes norvegica. Mar Ecol Progr Ser. 2005;289:225-35.

6. Alvarado Bremer JR, Vinas J, Mejuto J, Ely B, Pla C. Comparative phylogeography of Atlantic bluefin tuna and sword-fish: the combined effects of vicariance, secondary contact, introgression, and population expansion on the regional phylogenies of two highly migratory pelagic fishes. Mol Phyl Evol. 2005;36:169-87.

7. Viñas J, Pérez-Serra A, Vidal O, Alvarado Bremer JR, Pla C. Genetic differentiation between eastern and western Mediterranean swordfish revealed by phylogeographic analysis of the mitochondrial DNA control region. ICES J Mar Sci. 2010;67:1222-9.

8. Palero F, Abellò P, Macpherson E, Beaumont M, Pascual M. Effect of oceanographic barriers and overfishing on the population genetic structure of the European spiny lobster (Palinurus elephas). Biol J Linn Soc. 2011;104:407-18.

9. Babbucci M, Buccoli S, Cau A, Cannas R, Goñi R, Díaz D, Marcato S, Zane L, Patarnello T. Population structure, demographic history, and selective processes: Contrasting evidences from mitochondrial and nuclear markers in the European spiny lobster Palinurus elephas (Fabricius, 1787). Mol Phyl Evol. 2010;56:1040-50.

10. Elphie H, Raquel G, David D, Serge P. Detecting immigrants in a highly genetically homogeneous spiny lobster population (Palinurus elephas) in the northwest Mediterranean Sea. Ecol Evol. 2012;2:2387-96.

11. Alpar B, Yüce H. Sea level variations and their interactions between the Black Sea and the Aegean Sea. Estuar Coast Shelf Sci. 1998;46:609-19.

12. Fairbanks RG. A 17,000-year glacio-eustatic sea-level record: influence of global melting rates on the Younger Dryas event and deep-ocean circulation. Nature. 1989;342:637-42

13. Viaud-Martinez KA, Brownell RL, Komnenou A, Bohonak AJ. Genetic isolation and morphological divergence of Black Sea bottlenose dolphins. Biol Conserv. 2008;141:1600-11.

14. Viaud-Martínez KA, Martínez Vergara M, Gold'in PE, Ridoux V, Öztürk AA, Öztürk B, et al. Morphological and genetic differentiation of the Black Sea harbour porpoise Phocoena phocoena. Mar Ecol Progr Ser. 2007;338:281-94.

15. Yebra L, Bonnet D, Harris RP, Lindeque PK, Peijnenburg KTCA. Barriers in the pelagic: population structuring of Calanus helgolandicus and C. euxinus in European waters. Mar Ecol Progr Ser. 2011;428:135-49.

16. Zariquiey AR. Crustáceos Decápodos Ibéricos. Investigatión Pesquiera. 1968:32:1-510.

17. Ingle RW. British crabs. London: British Museum (Natural History). Oxford: Oxford University Press; 1980

18. Cannicci S, Paula J, Vannini M. Activity pattern and spatial strategy in Pachygrapsus marmoratus (Decapoda: Grapsinae) from Mediterranean and Atlantic shores. Mar Biol. 1999;133:429-35.

19. Cuesta JA, Rodriguez A. Zoeal stages in the intertidal crab Pachygrapsus marmoratus (Fabricius, 1787) (Brachyura, Grapsidae) reared in the laboratory. Hydrobiologia. 2000;436:119-30.

20. Fratini $S$, Schubart CD, Ragionieri L. Population genetics in the rocky shore crab (Pachygrapsus marmoratus) from the western Mediterranean and eastern Atlantic: complementary results from mtDNA and microsatellites at different geographic scales. In: Held C, Koenemann S, Schubart CD, editors. Crustacean issues 19: Phylogeography and population genetics in Crustacea. Boca Raton: CRC Press; 2011. p. 191-213.

21. Deli T, Fratini S, Ragionieri L, Said K, Chatti N, Schubart CD. Phylogeography of the marbled crab Pachygrapsus marmoratus (Decapoda, Grapsidae) along part of the African Mediterranean coast reveals genetic homogeneity across the Siculo-Tunisian Strait versus heterogeneity across the Gibraltar Strait. Mar Biol Res. 2016: doi: 10.1080/17451000.2016.1154972.

22. Fratini S, Zane L, Ragionieri L, Vannini M, Cannicci S. Relationship between heavy metal accumulation and genetic variability decrease in the intertidal crab (Pachygrapsus marmoratus) (Decapoda; Grapsidae). Estuar Coast Shelf Sci. 2008;79:679-86

23. Fratini S, Ragionieri L, Cutuli G, Vannini M, Cannicci S. Pattern of genetic isolation in the crab (Pachygrapsus marmoratus) within the Tuscan Archipelago (Mediterranean Sea). Mar Ecol Progr Ser. 2013;478:173-83.

24. Silva IC, Mesquita N, Schubart CD, Judite Alves M, Paula J. Genetic patchiness of the shore crab Pachygrapsus marmoratus along the Portuguese coast. J Exp Mar Biol Ecol. 2009;378:50-7.

25. Matzen da Silva J, Creer S, dos Santos A, Costa AC, Cunha MR, et al. Systematic and evolutionary insights derived from mtDNA COI barcode diversity in the Decapoda (Crustacea: Malacostraca). PLoS ONE. 2011; doi:10.1371/journal.pone.0019449

26. Patwary MU, Kenchington EL, Bird CJ, Zouros E. The use of random amplified polymorphic DNA markers in genetic studies of the sea scallop Placopecten magellanicus (Gmelin, 1791). J Shellfish Res. 1994;13:547-53.

27. Schubart CD, Huber MGJ. Genetic comparisons of German populations of the stone crayfish, Austropotamobius torrentium (Crustacea: Astacidae). B Fr Peche Piscic. 2006;380-381:1019-28.

28. Folmer O, Black M, Hoeh W, Lutz R, Vrijenhoek R. DNA primers for amplification of mitochondrial cytochrome c oxidase subunit I from diverse metazoan invertebrates. Mol Mar Biol Biotechnol. 1994;3:294-9.

29. Hall TA. BioEdit: a user-friendly biological sequence alignment editor and analysis program for Windows 95/98/NT. Nucleic Acids Symp Ser. 1999;41:95-8.

30. Kumar S, Tamura K, Nei M. MEGA3: Integrated software for Molecular Evolutionary Genetics Analysis and sequence alignment. Brief Bioinform. 2004;5:150-63.

31. Nei M. Molecular Evolutionary Genetics. New York: Columbia University Press; 1987.

32. Excoffier L, Laval G, Schneider S. Arlequin ver. 3.0: an integrated software package for population genetics data analysis. Evol Bioinform Online. 2005;1:47-50

33. Excoffier L, Smouse PE, Quattro JM. Analysis of molecular variance inferred from metric distances among DNA haplotypes: application to human mitochondrial DNA restriction data. Genetics. 1992;131:479-91.

34. Wright S. The genetical structure of populations. Annual Eugenics. 1951;15:323-54.

35. Tajima F, Nei M. Estimation of evolutionary distance between nucleotide sequences. Mol Biol Evol. 1984;1:269-85.

36. Benjamini $Y$, Hochberg $Y$. Controlling the false discovery rate: a practical and powerful approach to multiple testing. J R Statist Soc B. 1995;57:289-300.

37. Carvajal-Rodriguez A, de Uña-Alvarez J. Assessing significance in highthroughput experiments by sequential goodness of fit and q-value estimation. PLOS ONE 2011; doi: 10.1371/journal.pone.0024700

38. Peakall R, Smouse PE. GenAlEx 6.5: genetic analysis in Excel. Population genetic software for teaching and research - an update. Bioinformatics. 2012:28:2537-9.

39. Tajima F. Statistical method for testing the neutral mutation hypothesis by DNA polymorphism. Genetics. 1989;123:585-95.

40. Ramos-Onsins SE, Rozas J. Statistical properties of new neutrality tests against population growth. Mol Biol Evol. 2002;19:2092-100.

41. Fu YX, Li WH. Statistical tests of neutrality of mutations. Genetics. 1993;133:693-709.

42. Fu YX. Statistical tests of neutrality of mutations against population growth, hitchhiking and background selection. Genetics. 1997;147:915-25.

43. Librado P, Rozas J. DnaSP v5: a software for comprehensive analysis of DNA polymorphism data. Bioinformatics. 2009;25:1451-2.

44. Drummond AJ, Rambaut A, Shapiro B, Pybus OG. Bayesian coalescent inference of past population dynamics from molecular sequences. Mol Biol Evol. 2005;22:1185-92. 
45. Drummond AJ, Suchard MA, Xie D, Rambaut A. Bayesian phylogenetics with BEAUti and the BEAST 1.7. Mol Biol Evol. 2012;29:1969-73.

46. Darriba D, Taboada GL, Doallo R, Posada D. jModelTest 2: more models, new heuristics and parallel computing. Nat Methods. 2012;9:772.

47. Guindon S, Gascuel O. A simple, fast and accurate method to estimate large phylogenies by maximum-likelihood. Syst Biol. 2003;52:696-704.

48. Rambaut A, Drummond AJ. Tracer v 1.4.8. Institute of Evolutionary Biology, University of Edinburg, 2007. http://beast.bio.ed.ac.uk/Tracer. Accessed 12 July 2016.

49. Schubart CD, Diesel R, Hedges SB. Rapid evolution to terrestrial life in Jamaican crabs. Nature. 1998;393:363-5.

50. Simon C, Frati F, Beckenbach A, Crespi B, Liu H, Flook P. Evolution, weighting, and phylogenetic utility of mitochondrial gene sequences and a compilation of conserved polymerase chain reaction primers. Ann Entomol Soc Am. 1994:87:651-701.

51. Grant WS. Problems and cautions with sequence mismatch analysis and Bayesian Skyline Plots to infer historical demography. J Hered. 2015;106:333-46.

52. Stamatis C, Triantafyllidis A, Moutou KA, Mamuris Z. Mitochondrial DNA variation in northeast Atlantic and Mediterranean populations of Norway lobster. Nephrops norvegicus Mol Ecol. 2004;13:1377-90.

53. Reuschel S, Schubart CD. Phylogeny and geographic differentiation of Atlanto-Mediterranean species of the genus Xantho (Crustacea: Brachyura: Xanthidae) based on genetic and morphometric analyses. Mar Biol. 2006;148:853-66.

54. Reuschel S, Schubart CD. Contrasting genetic diversity with phenotypic diversity in coloration and size in Xantho poressa (Brachyura: Xanthidae), with new results on its ecology. Mar Ecol. 2007;28:296-305.

55. Schubart CD, Aichinger BE. Determination of evolutionary units in European representatives of the crab genus Pilumnus. Centr Eur J Biol. 2014;9:104-13.

56. García-Merchán VH, Robainas-Barcia A, Abelló P, Macpherson E, Palero F, García-Rodriguez M, et al. Phylogeographic patterns of decapod crustaceans at the Atlantic-Mediterranean transition. Mol Phylogenet Evol. 2012:62:664-72.

57. Sá-Pinto A, Branco MS, Alexandrino PB, Fontaine MC, Baird SJE. Barriers to gene flow in the marine environment: insights from two common intertidal limpet species of the Atlantic and Mediterranean. PLoS ONE. 2012;7:10.1371/ journal.pone.0050330

58. Stefanni S, Castilho R, Sala-Bozano M, Robalo Jl, Francisco SM, Santos RS, Marques N, Brito A, Almada VC, Mariani S. Establishment of a coastal fish in the Azores: recent colonisation or sudden expansion of an ancient relict population? Heredity. 2015;115:527-37.

59. Domingues VS, Bucciarelli G, Almada VC, Bernardi G. Historical colonization and demography of the Mediterranean damselfish. Chromis chromis Mol Ecol. 2005;14:4051-63.

60. Marino IAM, Pujolar JM, Zane L. Reconciling deep calibration and demographic history: Bayesian inference of post glacial colonization patterns in Carcinus aestuarii (Nardo, 1847) and C. maenas (Linnaeus, 1758). PLoS ONE. 2011; doi:10.1371/journal.pone.0028567

61. Kimura M, Weiss GH. The stepping stone model of population structure and the decrease of genetic correlation with distance. Genetics. 1964:49:561-76.

62. Slatkin M, Maddison WP. Detecting isolation by distance using phylogenies of genes. Genetics. 1990;126:249-60.

63. Ragionieri L, Schubart CD. Population genetics, gene flow and biogeographic boundaries of Carcinus aestuarii (Crustacea: Brachyura: Carcinidae) along the European Mediterranean coast. Biol J Linn Soc. 2013;109:771-90.

64. Hauser L, Carvalho G. Paradigm shifts in marine fisheries genetics: ugly hypotheses slain by beautiful facts. Fish Fish. 2008;9:333-62.

65. Karl SA, Toonen RJ, Grant WS, Bowen BW. Common misconceptions in molecular ecology: echoes of the modern synthesis. Mol Ecol. 2012:21:4171-89.

\section{Submit your next manuscript to BioMed Central and we will help you at every step:}

- We accept pre-submission inquiries

- Our selector tool helps you to find the most relevant journal

- We provide round the clock customer support

- Convenient online submission

- Thorough peer review

- Inclusion in PubMed and all major indexing services

- Maximum visibility for your research

Submit your manuscript at www.biomedcentral.com/submit
Biomed Central 